\title{
CHARACTERISTICS AND STRATEGIES TO IMPROVE CHINESE OUTBOUND TOURIST TRAVEL TO INDONESIA
}

\author{
I Gusti Ayu Dewi Hendriyani. \\ Sekolah Tinggi Pariwisata Nusa Dua Bali. \\ dewi.hendriyani2.gmail.com
}

\begin{abstract}
The tourism sector in Indonesia has been established as the main sector in the future. Visits of Chinese tourists ranked highest in 2017 than any other country. The huge potential of China's market in the world demands that the government together with tourism stakeholders jointly increase the number of Chinese tourists visiting Indonesia. This research is a literature study on the characteristics of Chinese outbound tourists from various sources, as well as strategies to increase the visit of Chinese tourists to Indonesia. The results of this literature review are expected to be an input for the development of tourism sector in Indonesia in reaching outbound tourists from China, and can be an inspiration for a suitable research theme in the future.
\end{abstract}

Keywords: Characteristic, Chinese Tourists, Strategies

\section{INTRODUCTION}

The trend of world tourism today has undergone many changes along with the development of information technology through digitalization media. Various world destinations have seen that the largest market today is China. In this introduction will be discussed related to the magnitude of China's tourism market in the world and the changes in trends in travel, especially overseas tours

Market China in this fast-paced time period gets the priority and attention of many world tourism destinations. According to the Central statistics bureau Indonesia (2017), the number of overseas trips (outbound) of Chinese citizens increased significantly from year to year. In Indonesia, the number of foreign tourists visiting China is highest, followed by Australia, Singapore, and Europe. Prediction says in 2030, Chinese will dominate the world outbound travel. Prior to 2030, more than 50\% of the world's traffic growth came from the Asia Pacific. As many as $49 \%$ of global traffic passengers will be in the Asia Pacific region or between these areas, as well as other regions. Tourists from China will hold a large share of this growth (about $40 \%$ of Asian tourists travel overseas). Specifically predicted before 2030, Chinese urban tourists will make 1.7 billion domestic and outbound travel each year, and spend $\$ 1.8$ trillion on tours - nearly 7 times their current spending

The distribution of Chinese tourists visiting the world is to Asia's largest continent to Japan and South Korea, to Europe's largest continent of France, Britain, Italy, to the continent of America and also the continent of Australia. For the visit of foreign tourists to China most Southeast Asia to the State of Singapore, Thailand, 
Malaysia, and Vietnam. The total outbound of Chinese tourists to Indonesia in 2017 is only $1,972,405$ million ( $1 \%$ of China's total outbound) with the most spread to destinations Bali, Jakarta, Tanjung Uban, Batam and Manado (Ministry of Tourism RI: 2017)

Tourism activity is currently growing rapidly in the world and its changes are strongly influenced by the development of information and technology. The current trend in China's first country started with a technological transformation in China based on digital. The development of 5G technology by the largest IT company in China that Huawei affects the various business decisions amazingly fast. Smile to pay system in the program settings facial recognition is with a smile on the 3D screen greatly accelerate the access business with remarkable results. The second trend is that the Chinese government is deeply committed to the development of the tourism industry. In line with the increasing economic development of Chinese citizens, since 1983 the Chinese government called for its citizens to travel abroad. China's government policy with Approve Destination Status (ADS) and the emergence of China's Tourism Act further clarify that the role of the Chinese government is enormous for its citizens when they travel especially abroad.

The third trend is the emergence of an economy class of Chinese society that has the ability to travel abroad. In terms of welfare and purchasing power is increasing. The fourth trend is a regulation of the social credit system that applies to Chinese citizens who are governed by the Chinese government. The government will monitor all of its citizens with bad behaviors that will impact on lending from banks, employment opportunities, and prevention of domestic and foreign travel. The Chinese government has big data to monitor its citizens. Moreover the fifth trend is the number of Chinese tourists who will increase rapidly within the next 2 years. According to CTrip, the number of overseas Chinese in 2020 is predicted to be around 240 million people (MarkPlus: 2018)

Tourism in Indonesia in the future is defined as a leading sector by the President of the Republic of Indonesia. The growth of tourism in Indonesia in 2017 increased 3-fold compared to regional and global growth. Growth of Indonesian tourists by $22 \%$, while the growth of ASEAN is only $7 \%$ and the world growth of only $6.4 \%$. For the neighboring countries of Vietnam, countries experienced a good growth of $29 \%$ while the country of Thailand at $8.7 \%$, Singapore $5.8 \%$, and Malaysia even minus $4 \%$. This shows that the performance of the Indonesian nation in increasing the number of visits by foreign tourists to Indonesia, especially by the Ministry of Tourism has shown a very extraordinary (Kemenpar: 2017)

According to the World Tourism Organization (WTO), outbound tours include tours conducted outside of the country of residence with a duration of less than one year for major purposes other than working in the country (business, leisure or other personal purposes). It should be noted that although "outbound travel" refers to the definition of tourism abroad, but in official statistics China, Hong Kong and Macao, two special administrative regions of China, are still included in the calculation of outbound tourists. However, today Chinese citizens can travel to Hong Kong and Macau with the "Individual Visitor Scheme" (IVS) program, which makes it easier for Chinese people to travel to Hong Kong and Macau compared to other international destinations (Choi, Liu, Pang, and Chow, 2008) . 
Tourism opportunities in Indonesia with 3 main entrances are Bali (40\%), Jakarta (30\%) and Batam Kepri (20\%) need a good strategy to achieve the target of foreign tourists visit in 2018 amounted to 17 million and 20 million in 2019. In 2017 the Ministry of Tourism had set 10 priority destinations in Indonesia with the 3 A development strategy of Access, Amenities and Attractions. Besides, the year 2018 has been designated as Visit Wonderful Indonesia (ViWI 2018) year, with 100 Wonder Event program and 100 Digital Destination in Indonesia. In the case of accelerated development of amenities, Kemenpar set a program of 100 Homestay on the destination with the development of local values and community-based and Nomadic Tourism development is to travel to destinations with nomadic accommodation such as Glamping, Caravan etc. Hope all of us all the program will succeed so that needed all support component of Indonesia (Rakornas Kemenpar: 2018)

Changes in psychography of the main markets of tourism in Indonesia is the Chinese market from mass tourism to special interest tourism. The development of IT led to more Chinese tourists active in seeking information through online media, social media and also recommendations from friends. From the conventional tour program through offline Travel Agent has changed its choice to online Travel Agent (OTA). What is interesting is the shift of interest from just traveling alone to want to get a different experience than before. In terms of the number of more who have chosen to travel independently (FIT) with spouses, friends or family than in groups (GIT). The China Millenial Market is more independent in determining its activities while in Destination when they conduct outbound (CNTA: 2017)

In line with the above changes and developments, Indonesia government has seen that the Chinese market should be worked well, see the potential number and purchasing power of Chinese tourists are growing and promising in the future. So the research related to the characteristics of Chinese tourists and the determination of strategies to increase the visit of Chinese tourists to Indonesia needs to get attention for all parties involved in Indonesia

In accordance with the above background, the purpose of this study is to determine the characteristics of Chinese tourists and strategies to increase the number of tourists visiting China to Indonesia. The results of this literature research can be an input for all tourism stakeholders in Indonesia especially to whom that handle Chinese tourists in Indonesia.

\section{METHODOLOGY}

This research is using qualitative method by doing study literature from many sources. This approach is expected to help researchers to understand the phenomenon under empirical study.

\section{RESULT}

The latest Chinese market profile based on a report from World Bank 2017, China Tourism Academy \& CTrip Report 2017 and World Economy Forum 2017 mentions China's population decline by 1.3 billion in 2016 with a $0.5 \%$ increase per year, per capita GDP averages per the population of 2016 amounted to 
USD 8.123 and increased $6.7 \%$ from the previous year (2015), the total inbound travel in 2016 was 138 million while the total outbound travel of 130 million in 2017. Data from TTCI China is ranked 15th in 2017 and total foreign travel expenditures in 2016 amounted to USD 109.8 billion with an increase of 5.1\% from a year earlier (2015)

Spending distribution of outbound tourists in China is reported in World Travel Report 2016 that the largest on shopping (52\%), followed by transportation (27\%), food (6\%), accommodation (5\%), and entertainment (2\%). The spending of Chinese outbound tourists is USD 499 to USD 3200. According to World Travel Reports 2016, overseas trips by Chinese will experience a steady increase in the years to come and will gradually begin to mature and better known as tourist travel styles from Western countries with various market segments. More precisely World Travel Reports predicts that Chinese tourists, who have been famous for their shopping habits in different parts of the world will begin to reduce their spending habits more rationally

Characteristic of Chinese outbound on the UNWTO report (2017) with the psychographics of Chinese millennium and the development of the Chinese Free Independent Traveler (FIT) market. Chinese millennials have demonstrated some unique characteristics. Chinese millennials perceive travel as more enjoyment and gaining an authentic life experience than as purchasing a product, love to share, demand their products and services be smaller, faster and more flexible, love shopping and value the freedom of self expression inherent on creating their own styles, internet is an indispensable part of their outbound travel. There are 3 segmented outbound Chinese Tourists Source Market, Tier 1 tourists in generating regions, they are increasing demands for high-end and luxury tour product, Tier 2 tourists in generating regions, they prefer conventional sightseeing products and still occupy an important position and Tier 3 tourists in generating regions, its infancy and traditional sightseeing products are still norms.

Results of research by Weinswig (2017) related Chinese outbound tourists-more diverse, more sophisticated with 841 samples get 3 important keys: 1). Chinese outbound tourists $(67 \%)$ have traveled more than once in the past 12 months, 2). Chinese outbound tourists from lower tier cities have become the growth engine for outbound tourism. They spend USD 2.449 average and travel average 1.9 times per year more than from Tier one cities, 3). Chinese tourists are mobile savvy (98\%) to keep in touch with others and search for travel related information. They used online resources (72\%) such as travel websites, blogs, social media to plan their trips. Security, tourists spots and cuisine are the most consideration for choosing destination. Clothing, footwear, accessories and meals are the most popular category purchased in duty free and department store.

The profile of Chinese outbound tourists in Indonesia is based on data from Passenger Exit Survey (PES) and data from Central Statistics Bureau Indonesia in 2016, experiencing a growing number of visits increased by $4.3 \%$, tourism activity is rural / urban (88\%), marine (53\%), art and culinary (52\% and cultural / spiritual (30\%) .The ages of Chinese tourists are generally around 25-34 years old. Voyage motivation is $67 \%, 88 \%$ of event / MICE (20\%), Visit Family and Relative (VFR) 88\%. information to visit Indonesia is friends / relatives (54\%), internet $(41 \%)$, social media $(32 \%)$. The average length of stay of Chinese tourists is 7.12 days with spending per visit USD 1,019 and per day USD 143. The entry 
into Indonesia's largest to Bali, followed by Jakarta, Tanjung Uban, Batam and Manado (Ministry of Tourism RI : 2018)

The number of visits by Chinese tourists in Bali in 2017 according to Central Statistics Bureau of Bali is around 900.000 persons followed by Australia and Japan. Chinese tourists have significantly increased the number of visits from year to year to Bali and are now the first to beat Australia. The handling of Chinese tourists in Bali is mostly by 40 Travel Agents (TA) who specialize in handling Chinese tourists who are all members of ASITA (Travel Agent Association) special division of Mandarin which is often called Bali Liang. Bali has also been done improving facilities for Chinese tourists such as accommodation, restaurants and shopping centers. Hotels, restaurants and souvenir centers provide mandarin language information other than English. Including the increasing competence of Mandarin guides in the Association of Indonesian Guides (HPI) there has been an increasing number of mandarin mandarin guides that almost 5,000 people in 2018.

The journey of Chinese Traveller to Bali start with step 1: inspiration : to make shortlist desired options based on emotional connection to and images of destinations, step 2 : planning : 98\% Chinese look for information online on travel search engine, blogs, social medias and price is one of the most search aspects, step 3 : booking : Free Individual Traveller (FIT) mostly booked trip by online and Group Incentive Traveller (GIT) prefer booking through agent (offline), step 4 : travelling : travel peak periods : January, February, July and October with average stay 2-4 nights for FIT and 4-7 nights for GIT, step 5 : staying : Chinese tourists prefer to economize on food, accommodation and transportation but become lavish when it comes to shopping, step $6:$ technology : Chinese tourist make extensive use of digital technology while on travel $2 / 3$ of Chinese use blogs, or have personal web space, step 7 : Like and dislikes : Chinese mostly likes unique arts and culture, nature (water sport), and blue skies, shopping of local products. They are frustrated to use their language or credit card, step 8 : Sharing : once back home, Chinese travelers share their experience in person or on social media (Sina, Weibo, Tencent, etc), to improve their status (European Commission and Bali Liang: 2017)

Research about Chinese Tourists satisfaction in Bali conduct by Bali Tourism Institute (BTI) started since 2012 until now through BTI research unit. First, research about shopping behavior Chinese Tourists in Bali (Hendriyani: 2012) with 104 sample findings for shopping pattern to Chinese Tourists during their stay at Bali. The findings are: Chinese tourist likes to shop at traditional Bali souvenir shop, buy a lot of wallet product, get information from their guide, shopping for 3 days, with local currency (rupiah) and shopping based of friends and relatives recommended. (B) prefer the need for fitting room facilities, for salesperson service (C) they need good product knowledge and for store policy (D) ) likes after sales service. Results of this research can be taken into consideration for all stakeholders or parties who handle Chinese tourists, especially for entrepreneurs who handles Chinese tourists in Bali. Second, research about satisfaction analysis of Chinese Tourists at Chinese Restaurants in Badung Regency of Bali with 110 respondents findings that the whole is in good condition. Using analysis factor with Parasuraman ServQual model, the factor that most determines is Food and Beverage factor, followed by Service factor. While most decisive variable is taste followed by variable Air Conditioning. The results of this study can be used as inputs for 
Chinese tourism companies in China (Hendriyani: 2016). Third, research about Chinese tourists at Nusa Dua Tourism Area of Bali with 117 sample of Chinese Traveler who is staying at 10 hotels in Nusa Dua Tourism Resort of Bali. In three months (June-August 2016) with sampling technique uses accidental sampling. The analysis used was validity and reliability, quantitative analysis using a Likert scale. The Nusa Dua Tourism Resort of Bali is an excellent or satisfactory category (Hendriyani: 2017)

Based on the strategic plan kemenpar 2014-2019 policy and strategy of tourism development Indonesia has been formulated to contain several strategies such as tourism marketing strategy, development of tourist destinations, development of tourism industry, the development of tourism institutions and development of tourism infrastructure. Research on the Indonesian government's strategy of attracting foreign tourists uses the SWOT analysis to generate policy recommendations, namely the opportunity power strategy by promoting a more aggressive strategy, the weakness of opportunities by developing better infrastructure, the threat strength strategy by strengthening comparative and competitive advantages and strategy of threat weakness by increasing promotion and packaging of Indonesian tourist destination with different and unique ways (Sujai : 2016)

The number of visits by Chinese tourists to Indonesia in 2017 is 1,972,405 people (only $1 \%$ of total outbound Chinese traveler). The biggest entrance to Indonesia is Bali, followed by Jakarta, Tanjung Uban, Batam and Manado. In fact, Bali's destination has always been a priority for foreign tourists, especially foreign tourists. Changing the focus from Bali to other destinations in Indonesia will make us have to deal with various issues of perception. The fact that the absence of direct flights from China to Indonesia is not a major issue for tourists from China. However the more focused is the issue of criminal, terrorist and journey duration in addition to illness / hygiene, language and payment problems through digital means (mobile app) (Kemenpar: 2017)

The policy of the Ministry of Tourism of Republic of Indonesia (RI) to increase the visit of Chinese tourists begins by signing Memorandum of Understanding (MoU) with China National Tourism Administration (CNTA) in order to encourage the increase of foreign tourists visit in both countries by 2017 . Furthermore Minsitry of Tourism RI also partnerships with provincial tourism agencies and online tourist agencies China's largest, Ctrip (China Trip). This tour agent controls $60 \%$ of China's outbound market by pocketing 60 million subscribers

Efforts to increase flight connectivity from China to Indonesia receive special attention from the Indonesian government. For China's total seat seat capacity of 2.3 million seats / year, for Macau total seat capacity of 37 thousand seats / year and from Hong Kong total seat capacity of 1.1 million seats / year to Denpasar, Jakarta, Surabaya and Manado. The area of origin is divided into areas of China I (Beijing, Xi'an, Zhengzhou including Macau and Hongkong), China II (Guangzhou, Shenzen), China III (Shanghai, Hangzhou, Nanjing, Nanchang and Gullin) and China IV ( Chengdu, Changsha, Haikou, Xiamen, Wuhan, Fuzhou, Quanzhou) (Ministry of Transportation: 2017)

Promotion strategy by Indonesia government to China is done by focusing on following world events such as exhibition, sales mission, festival, and fam trip. 
The exhibition is one of tourism promotion strategy of Ministry of Tourism in promoting Indonesia tourism destination by participating in international tourism exhibition. The purpose of the tourism exhibition is to promote the destination and tourism products of Indonesia in foreign countries. Types of exhibitions conducted are public tourism exhibitions and special interest tourism exhibitions. Sales Mission is one of tourism promotion activities conducted abroad in order to increase the number of foreign tourists by facilitating Travel Agent (TA) / Travel Operator (TO), hotelier, domestic tourist attraction (as seller) to make business contact ( business matching) with the foreign TA / TO industry (as buyer) or with a particular community. Sales Mission there are 2 types of common sales mission of special interest tourism sales. The purpose of sales mission is to encourage the existence of Indonesian tourism industry abroad. Sales mission implementation method is with direct promotion, table top and business networking. While the Festival is a festive event made in order to commemorate something. The purpose of the festival as a medium of imaging, development, art and culture in introducing and preserving art and culture. The festival consists of art and cultural festivals, sports, culinary, and music which are attractions for tourists. And the last is FamTrip is bringing a group of people to visit the destination and improve the image of Indonesian tourism and increase new opportunities and cooperation between participants with pariwiata industry in Indonesia. FamTrip participants are usually from travel agency, media and endorsers (Minsytry of Tourism : 2017)

July and August are the top overseas trips for Chinese tourists. Best time for promotional activities to China by looking at China Holiday Season and China School Holiday Season. Chinese New Year and Golden Week Chinese citizens usually focus more on domestic flights that Chinese people use to visit their families. In the 2nd semester each year is still high due to holidays in October and other celebration holidays. As of 2018 there are 6 China Holiday Season: 11-25 February (Chinese New Year), 1-8 April (Labor Holiday), 15-20 June (Dumpling Festival), 29 September-7 October (National Holiday), 24 December-1 January (Year End Holiday). On the other side there are 2 China School Holiday Season which is January 26th - February 22nd (Winter Holiday) and July 14th to August 31st (Summer Holiday) (Kemenpar: 2017)

Recommendations from UNWTO (2017) market solutions and approaches to attract Chines Tourist to destination are 1). studying and appreciating the tourist characteristics and segmentations of sub-markets, 2). preparing the destination and local tourism suppliers to welcome an influx of Chinese tourists, developing the phased market entry plan a regional market penetration plan to explore the market potential, 3). creating targeted and differentiated products, 4). building close and long-lasting relationships with Chinese tourism stakeholders, 5). promoting the destinations through different local media channels, 6). establishing a presence in China preferably in the main generating areas through national tourism offices, 7). consulates, airlines outlets, adopting policies aimed at travel facilitation such as good airline connectivity, 8). smooth and trouble-free visa issuance, and 9). assuring that safety and security measures are duly respected.

Model OMNI-Way marketing strategy by MarkPlus Center (2018) was socialized through the Seminar Winning and Optimizing Chinese Tourist throughs: OMNY-Way in Denpasar Bali, attended by all tourism stakeholders in Bali, including from Minsitry of Tourism RI proposes three things in order to increase 
visits of Chinese tourists to Indonesia. 3 proposed strategies are Tourist Management, Destination Management and Brand Management. Tourist Management consists of servicing Chinese tourist, learn about the trend, tourist behavior and tourist perception. Destination Management consists of developing China ready, destination and business. While Brand Management consists of managing China digital media

The synergy of tourism pentahelic element that is academic, business, society, government and media in Indonesia to increase the number of foreign tourist visit especially chinese tourists to Indonesia is needed. The results of the discussions in several Tourism Seminars and Focus Group Discussions in Indonesia provide a positive response to the preparation of destinations in Indonesia to be ready to receive Chinese tourists. Various efforts to improve in providing the best service for Chinese tourists have been done to maintain the reputation of tourism in Indonesia as a whole. These include Mandarin language training for frontliners, mandarin use in guides as well as tourism information, additional capacity of direct flights from China to destinations in Indonesia, publications through digital media on Chinese etc. Moreover, if there are problems that arise related services for Chinese tourists can be done together by all relevant pentahelic elements.

Implication for industry, as the market landscape for Chinese tourists transforms and to be more sophisticated, brands and retailers need to adopt and update their strategy of continuously in order to engage this large and growing market of consumers. Chinese tourists have disbandified demographics and travel experiences, so have different needs while traveling abroad. Industries should identify their target tourists segments and cater to their needs accordingly. And industries should engaged with Chinese tourists online at every stage of their trip, apart from conventional advertising, encouraging Chinese tourists to share their experiences at retail outlets is more influential, as it reaches new potential customers. And implications for governments, media, academic and community to better synergize in efforts to improve the quality of service for Chinese tourists in their respective fields

\section{CONCLUSIONS}

With the increasing number of Chinese outbound tourists from year to year, it is necessary to make much effort to attract Chinese tourists to travel to Indonesia. By understanding the behavior of Chinese tourists abroad, Indonesian tourist stakeholder can customize the products and services offered to meet the needs of tourists China. With the fulfillment of the needs of Chinese tourists in their travels in Indonesia, the level of satisfaction of Chinese tourists will increase and can produce multiple effects for Indonesia's tourism industry.

With reference to the characteristics of Chinese tourists and the strategies to attract more Chinese tourists to Indonesia as described above, some things that can be done by the stakeholder of tourism in Indonesia as follows: 1). preparing the destination to welcome Chinese tourists, 2). creating targeted and differentiated products, 3). building close and long-lasting relationships with Chinese tourism stakeholders, 4). promoting the destinations through different local media channels, 5). consulates, airlines outlets, adopting policies aimed at travel facilitation such as good airline connectivity, free visa issuance etc. 


\section{References}

Alizila News. 2017. China's Digital Transformation. Alibaba- China

COTRI. 2018. China is the largest Outbound Tourism Market. Chinese Outbound Tourism Research Institute. The COTRI weekly- China

CNTA.2017. The trend of Chinese Outbound. CNTA- China

Hendriyani, D.2012. Faktor yang menjadi penentu kepuasan wisatawan China Group Inclusive Tour (GIT) terhadap produk restoran China di kabupaten Badung- Bali. Jurnal Kepariwisataan STP Nusa Dua Bali

Hendriyani, D.2016. Shopping behavior Chinese Tourists in Bali. Atlantis Press: Asia Tourism Forum 2016. ISBN: 978-94-6252-201-5. ISSN: 2352-5428

Hendriyani, D.2012. Chinese tourist perception on service quality at Hotel in Nusa Dua Tourism Resort-Bali. ApaCHrie Event 2017. http://apacchrie 2017.com/proceedings-rev3.pdf

Kemenpar.2018. Sinergitas Promosi Pariwisata Pasar Tiongkok. Bimtek Pasar China. Bali

Kemenpar.2018. Profil Wisman Tiongkok (great China). Jakarta

Kotler, et.al.1999. Characteristic of Tourists.

Markplus Center.2018. Winning and Optimizing Chinese Tourist through : OMNYWAY seminar. Bali

Purwanto and Ling. 2016. Analisis Prilaku Wisatawan Tiongkok di Luar Negeri: Sebuah Studi Literatur. Jurnal Bina Ekonomi volume 20, nomor 1, 2016. Jakarta

Sujai, M. 2016. Strategi Pemerintah Indonesia dalam menarik kunjungan turis mancanegara. Government Strategy Attract International Tourist. Kajian Ekonomi \& Keuangan. http://fiskal.depkeu.go.id/e-journal

UNWTO. 2017. Penetrating the Chinese Outbound Tourism Market. Succesful Practice and Solutions. www. E-unwto.org

Walsh, J. 2016. Chinese Tourism in Thailand. Experiences and Satisfaction. ASEAN Journal on Hospitality on Tourism, volume 6. Sinawatra University, Bangkok. Thailand

Weinswig, D. 2017. Deep Dive: Chinese Outbound Tourists-More Diverse, More Sophisticated. Fung Global Retail \& Technology. China 
$\mathrm{Xu}, \mathrm{F}$ and Wang,S. 2014. China's Outbound Tourism-Emerging Trends and Features in the second decade of the $21^{\text {st }}$ century. Perspectives in Asian Leisure and Tourism 